\title{
IMPLEMENTASI RANCANGAN E-COMMERCE PADA SURYA TIMUR COLLECTION DENGAN METODE BUSINESS MODEL CANVAS (BMC) BERBASIS CONTENT MANAGEMENT SYSTEM (CMS)
}

\author{
Farhan Ramadhan ${ }^{1)}$, Lusi Fajarita ${ }^{2}$ \\ ${ }^{1}$ Sistem Informasi, Fakultas Teknologi Informasi, Universitas Budi Luhur \\ ${ }^{1,2} \mathrm{Jl}$. Raya Ciledug, Petukangan Utara, Kebayoran Lama, Jakarta Selatan 12260 \\ E-mail : faramdan30@gmail.com ${ }^{1)}$, lusi.fajarita@budiluhur.ac.id ${ }^{2)}$
}

\begin{abstract}
Abstrak
Surya Timur Collection adalah sebuah badan usaha perorangan yang bergerak di bidang penjualan pakaian pria dan wanita yang berlokasi di Jl. Margonda Raya No.56, Pancoran Mas, Depok, Jawa Barat. Dalam melakukan penjualan, Surya Timur Collection memiliki kendala dalam melakukan pengelolaan data penjualan dan belum tersedianya media untuk mempromosikan dan memasarkan produk-produknya ke masyarakat luas. Hal itu dapat berimbas bagi kemajuan toko tersebut di masa yang akan datang. Oleh karna itu, Surya Timur Collection sudah harus memanfaatkan teknologi internet untuk mengembangkan website E-Commerce (Electronic Commerce) untuk dapat mempromosikan produk yang tersedia ke masyarakat luas dan dapat memudahkan konsumen untuk melakukan transaksi di toko mereka. Dengan merancang sistem E-Commerce, diharapkan mampu memberikan dampak positif bagi Surya Timur Collection. Sehingga dapat mempermudah kegiatan penjualan serta mampu bertahan dan bersaing dengan seluruh badan usaha serupa yang memanfaatkan teknologi seperti yang ada saat ini. Penulis terlebih dahulu menganalisa menggunakan Bussines Model Canvas (BMC), setelah itu penulis mengimplementasikan sistem E-Commerce dengan menggunakan Wordpress. Penulis berharap dengan adanya perancangan sistem penjualan online E-Commerce dapat mempermudah proses penjualan yang ada dan dapat membantu mengatasi masalah-masalah yang terjadi pada Surya Timur Collection.
\end{abstract}

Kata kunci: Perancangan, E-Commerce, Wordpress, BMC

\section{PENDAHULUAN}

Seiring dengan kemajuan teknologi dan hadirnya internet di Indonesia saat ini, internet sudah menjadi kebutuhan di dalam kehidupan masyarakat sehari-hari. Karena dengan teknologi internet, masyarakat di Indonesia dapat berkesempatan untuk mencari informasi dan menikmati konten-konten yang diinginkan. Oleh karena itu sebagian masyarakat di Indonesia sudah memiliki telepon pintar (smartphone) di dalam saku mereka.

Perkembangan internet saat ini sangat membantu dalam perkembangan E-Commerce (Electronic Commerce) di dunia, sehingga dapat mencetuskan metode berbelanja yang sangat efisien bagi masyarakat dengan melalui telpon pintar (smartphone) tanpa batasan tempat dan waktu. Banyak efek-efek positif dari kemajuan teknologi $E$ Commerce di Indonesia, salah satunya yaitu berubahnya pola pikir belanja masyarakat yang dari bersifat tradisional hingga kini masyarakat sudah mau bertransaksi suatu produk atau jasa melalui website E-Commerce.

Surya Timur Collection adalah sebuah badan usaha yang bergerak di bidang penjualan pakaian pria dan wanita yang masih menggunakan cara tradisional dalam melakukan melakukan proses transaksi, dan belum tersedianya media untuk mempromosikan dan memasarkan produkproduknya ke masyarakat luas. Hal itu dapat berimbas bagi kemajuan toko tersebut di masa yang akan datang.

Oleh karna itu, Surya Timur Collection sudah harus memanfaatkan teknologi internet untuk mengembangkan website toko online atau $E$ Commerce untuk dapat mempromosikan produk yang tersedia pada Surya Timur Collection ke masyarakat luas dan dapat memudahkan konsumen untuk melakukan transaksi di toko mereka.

Adapun beberapa masalah yang terjadi pada Surya Timur Collection adalah sebagai berikut:

1. Media untuk mempromosikan dan memasarkan produk ke masyarakat kurang maksimal.

2. Kesulitan dalam mengetahui produk yang digemari konsumennya.

3. Pengelolaan stok barang masih menggunakan cara tradisional dalam sehingga stok barang kurang terpantau.

4. Data penjualan sering hilang dikarenakan tempat penyimpanan data penjualan kurang baik.

\section{STUDI LITERATUR}


a. Definisi Penjualan

Suatu kegiatan yang ditunjukan untuk mencari pembeli, memengaruhi, dan memberikan petunjuk agar pembeli dapat menyesuaikan kebutuhannya dengan produk yang ditawarkan serta mengandakan perjanjian mengenai harga yang menguntungkan bagi kedua belah pihak[1].

b. Definisi E-Commerce

Metode transaksi yang terjadi dalam jaringan internet yang dapat menjual beraneka barang atau jasa melalui komputer atau perangkat yang telah terhubung dengan internet.

c. Definisi Content Management System

Sebuah sistem berbasis website yang bertujuan untuk memberikan kemudahan kepada penggunanya dalam mengelola dan mengatur pada sebuah website seperti menambahkan menu, menerbitkan atau menghapus laman, hingga mengatur menu dan tampilan pada sebuah website tanpa harus mempunyai pengalaman dalam membuat website.

d. Definisi Business Model Canvas

Sebuah metode yang digunakan dalam mengatur dan mengelola strategi bisnis yang dibentuk secara visual agar lebih mudah dipahami oleh penggunanya. Business Model Canvas (BMC) memiliki 9 (sembilan) bagian, yaitu:

1) Key Partners

Sebuah metode yang menggambarkan pihak-pihak apa saja yang akan atau telah bekerja sama dengan sebuah perusahaan sehingga proses bisnis dapat dilaksanakan.

2) Key Activities

Sebuah metode yang menggambarkan kegiatan apa saja yang biasa dilakukan pada sebuah perusahaan saat terjadinya proses bisnis.

3) Key Resources

Sebuah metode yang menggambarkan sumber daya apa saja yang telah dimiliki suatu perusahaan sehingga proses bisnis dapat dilaksanakan.

4) Value Proposition

Sebuah metode yang menggambarkan nilai-nilai atau kelebihan apa saja yang telah dimiliki suatu perusahaan dari perusahaan lain yang mempunyai badan usaha yang sama.

5) Customer Relationship

Sebuah metode yang menggambarkan strategi atau cara yang digunakan sebuah perusahaan agar dapat lebih dekat dengan konsumennya.

6) Channels

Sebuah metode yang menggambarkan strategi yang digunakan untuk menyampaikan acara atau event yang sedang berlangsung pada sebuah perusahaan melalui sebuah media kepada konsumennya.

7) Customers Segments

Sebuah metode yang menggambarkan target pembelian atau target konsumen yang telah sesuai dengan badan usaha dari sebuah perusahaan.

8) Cost Structure

Sebuah metode yang menggambarkan biaya-biaya apa saja yang telah dikeluarkan pada sebuah perusahaan agar terjadinya proses bisnis.

9) Revenue Streams

Sebuah metode yang menggambarkan biaya-biaya yang akan atau telah didapatkan saat terjadinya proses bisnis pada sebuah perusahaan.

Berikut adalah beberapa alat yang digunakan dalam pengembangan penelitian ini, yaitu:

1) Hosting

Hosting merupakan tempat untuk menyimpan data-data website, sehingga dapat diakses lewat internet. Data tersebut disimpan dalam komputer server[2].

2) Domain

Nama yang digunakan suatu pemilik website atau blog agar alamat website mereka mudah dihafal[3].

3) Website

Salah salah satu alat komunikasi berupa pemasaran online interaktif yang dirancang untuk melibatkan pelanggan agar dapat meningkatkan kesadaran dan citra merek, atau memicu penjualan produk dan jasa[4].

4) Wordpress

Sebuah software yang berbasis website dan bersifat open-souce yang bertujuan untuk membuat website dan mampu untuk memanipulasi tampilan website yang disesuaikan dengan kebutuhan penggunanya[5].

5) WooCommerce

Sebuah plugin yang bersifat opensources yang digunakan untuk menyempurnakan atau mengubah Wordpress ke dalam sistem E-Commerce dengan mudah.

6) Microsoft Visio

Sebuah program aplikasi komputer yang digunakan untuk membuat diagram, flowchart, brainstorm, dan skema jaringan yang dirilis oleh Microsoft Corporation[6].

7) Balsamiq Mockup 
Sebuah perangkat lunak (software) yang berguna untuk mendesain tampilan/antarmuka/user interface pada website[7].

\section{METODE PENELITIAN}

\subsection{Metodologi Pengumpulan Data}

Dalam menyelesaikan penyusunan penelitian ini, penulis membutuhkan data-data yang berhubungan dengan studi kasus. Berikut adalah beberapa cara yang digunakan dalam melakukan metodologi pengumpulan data, yaitu:

a) Wawancara (Interview)

Penulis ini dilakukan dengan cara mengumpulkan informasi-informasi yang berkaitan dengan masalah dan kebutuhan agar mendapatkan informasi mengenai masalah dan kebutuhan yang diinginkan oleh pengguna.

b) Pengamatan (Observation)

Penulis ini dilakukan dengan cara mengumpulkan data dengan cara mengamati langsung ke tempat riset yang bertujuan untuk mengetahui bagaimana proses bisnis yang terjadi pada Surya Timur Collection.

c) Analisa Dokumen

Penulis ini dilakukan dengan cara mengumpulkan data berdasarkan dokumen-dokumen yang berhubungan dengan objek penelitian yang akan dianalisa lebih lanjut.

d) Studi Literatur

Penelitian ini dilakukan dengan cara mengambil dari berbagai buku serta referensi lain seperti e-book yang sesuai bedasarkan dengan permasalahan yang diamati.

\subsection{Langkah-Langkah Penelitian}

Berikut adalah beberapa langkah-langkah penelitian yang dilakukan oleh penulis dalam menyelesaikan penelitian ini yang bertujuan untuk memberikan solusi dari permasalahan yang ada bedasarkan studi kasus. Dapat dilihat pada gambar 1 .

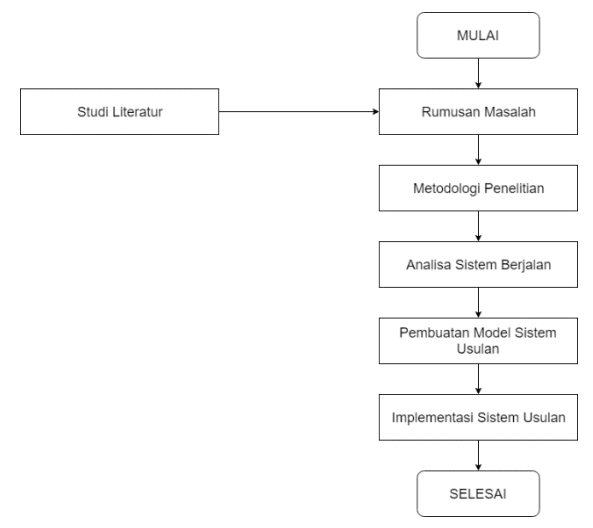

Gambar 1. Langkah-Langkah Penelitian
Bedasarkan gambar diatas, terdapat beberapa langkah-langkah penelitian yang digunakan untuk menyusun penelitian ini, yaitu:

1) Perumusan Masalah

Rumusan Masalah merupakan suatu langkahlangkah penelitian yang dilakukan dengan cara mengumpulkan data-data hasil dari informasi yang didapatkan dalam kegiatan pengumpulan data yang dilakukan dengan cara observasi dan wawancara langsung kepada informan yang terkait pada Surya Timur Collection.

2) Studi Literatur

Studi Literatur merupakan suatu langkahlangkah penelitian yang dilakukan dengan cara mendapatkan teori-teori yang berkaitan dengan studi kasus dan teori umum yang terkait dengan rumusan permasalahan. Metode yang dilakukan penulis yaitu dengan membaca berbagai referensi dari artikel atau skripsi yang telah dipublikasikan.

3) Metodologi Penelitian

Metodologi Penelitian merupakan suatu langkah-langkah penelitian yang dilakukan dengan cara mulai menentukan metodologi yang akan digunakan dalam menyelesaikan masalah penelitian. Metodologi yang digunakan dalam penelitian ini adalah menggunakan pendekatan Research Applied (Penelitian Terapan).

4) Analisa Sistem Berjalan

Analisa Sistem Berjalan merupakan suatu langkah-langkah penelitian yang dilakukan dengan cara penulis mulai melakukan analisa proses bisnis yang ada pada Surya Timur Collection menggunakan Activity Diagram, dan Business Model Canvas.

5) Pembuatan Sistem Model Usulan

Pada tahap ini, penulis mulai melakukan identifikasi kebutuhan apa saja yang harus ada di dalam sistem usulan, lalu penulis memodelkan hasil identifikasi sistem usulan tersebut dengan menggunakan Use Case Diagram, dan memodelkan data-data tersebut dengan Class Diagram.

6) Implementasi Sistem Usulan

Dan ditahap terakhir ini, penulis mulai mengimplementasikan model sistem usulan menggunakan Content Management System (CMS) yaitu Wordpress.

\section{HASIL DAN PEMBAHASAN}

Sistem penjualan pada Surya Timur Collection masih dilakukan dengan cara konvensional yaitu dengan melakukan pelayanan yang manual kepada pelanggannya. Oleh karna itu penulis menyusulkan sebuah sistem E-Commerce agar dapat mempermudah proses transaksi yang ada di Surya Timur Collection yang dapat dilakukan secara online tanpa batasan waktu. 
Berikut adalah tahapan-tahapan analisa sistem usulan yang terdapat pada Surya Timur Collection yang nantinya akan digambarkan dengan Activity Diagram, yaitu sebagai berikut:

\subsection{Activity Diagram}

Acivity Diagram merupakan sebuah metode analisa dari sebuah alur aktivitas proses bisnis yang terjadi pada sebuah perusahaan. Berikut adalah Activity Diagram yang terjadi pada proses bisnis Surya Timur Collection, yaitu:

1) Proses Pendaftaran

Pada Activity Diagram Proses Pendaftaran. Terdapat suatu proses yang bertujuan untuk melakukan pendaftaran untuk konsumen. Dapat dilihat pada gambar 2 .

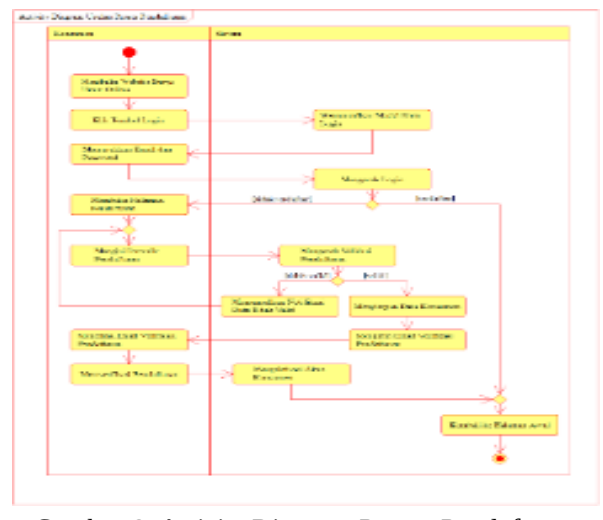

Gambar 2. Activity Diagram Proses Pendaftaran

\section{2) Proses Pemesanan}

Pada Activity Diagram Proses Pemesanan. Terdapat suatu proses yang bertujuan untuk melakukan pemesanan untuk konsumen. Dapat dilihat pada gambar 3 .

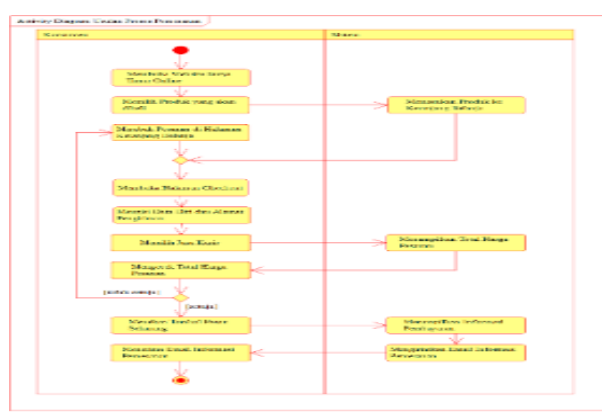

Gambar 3. Activity Diagram Proses Pemesanan

\section{3) Proses Pembayaran}

Pada Activity Diagram Proses Pembayaran. Terdapat suatu proses yang bertujuan untuk melakukan pembayaran suatu pemesanan konsumen. Dapat dilihat pada gambar 4.

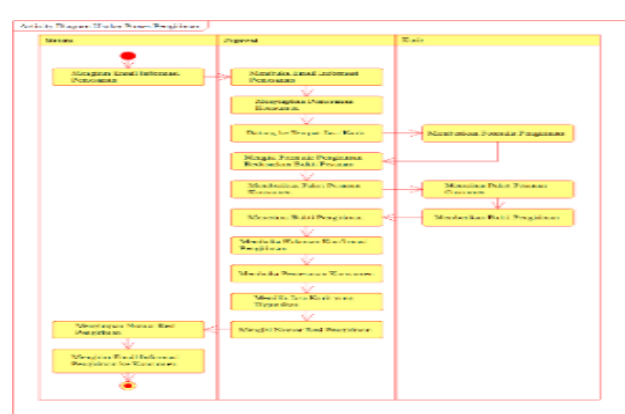

Gambar 4. Activity Diagram Proses Pembayaran

\section{4) Proses Pengiriman}

Pada Activity Diagram Proses Pengiriman. Terdapat suatu proses yang bertujuan untuk melakukan pengiriman bedasarkan pemesanan konsumen. Dapat dilihat pada gambar 5.

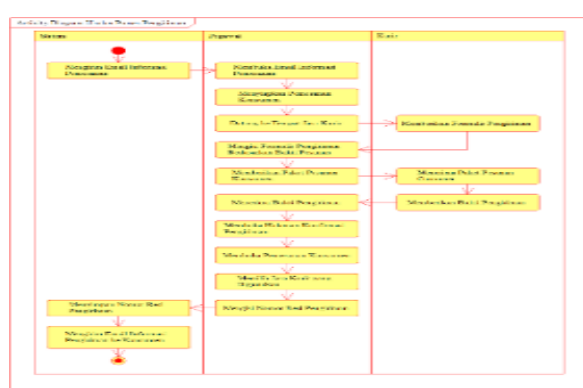

Gambar 5. Activity Diagram Proses Pengiriman

5) Proses Penerimaan Barang

Pada Activity Diagram Proses Penerimaan Barang. Terdapat suatu proses yang bertujuan untuk melakukan konfirmasi penerimaan barang dari konsumen. Dapat dilihat pada gambar 6 .

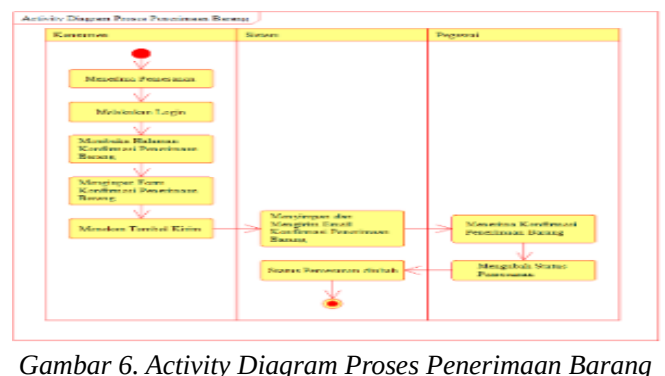

6) Proses Laporan Penjualan

Pada Activity Diagram Proses Laporan Penjualan. Terdapat suatu proses yang bertujuan untuk mencetak laporan penjualan bedasarkan periodenya. Dapat dilihat pada gambar 7. 


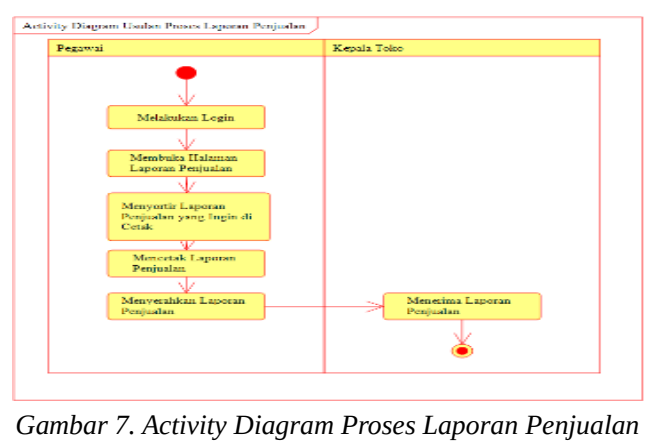

\subsection{Use Case Diagram}

Gambaran dari beberapa atau seluruh actor dan use case dengan tujuan mengenali interaksi mereka dalam suatu sistem[8].

\section{1) Use Case Diagram Master}

Pada Use Case Diagram Master. Terdapat input data produk, input kategori, input kurir, dan input data konsumen. Dapat dilihat pada gambar 8.

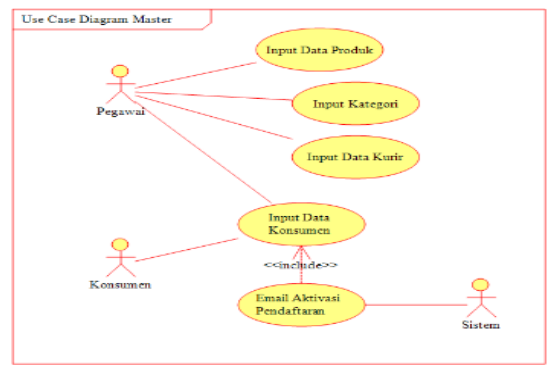

Gambar 8. Use Case Diagram Master

2) Use Case Diagram Transaksi

Pada Use Case Diagram Transaksi. Terdapat input pemesanan, input pembayaran, input bukti pembayaran, input penerimaan barang, dan input bukti pengiriman. Dapat dilihat pada gambar 9.

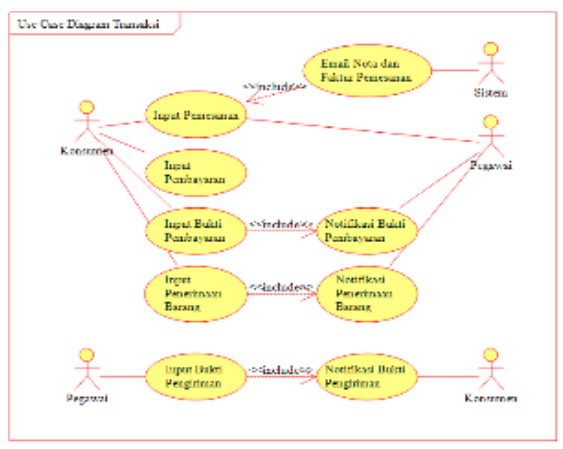

Gambar 9. Use Case Diagram Transaksi

3) Use Case Diagram Laporan

Pada Use Case Diagram Laporan. Terdapat cetak laporan penjualan, cetak laporan pengiriman, cetak laporan pembayaran, cetak laporan penerimaan barang, cetak laporan stok barang, dan cetak laporan rekapitulasi pendapatan. Dapat dilihat pada gambar 10.

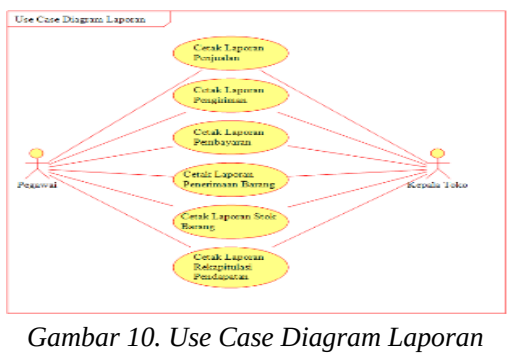

\subsection{Class Diagram}

Pada Class Diagram. Terdapat model relasi antar table yang disusun bedasarkan dengan program yang telah dibuat. Dapat dilihat pada gambar 11 .

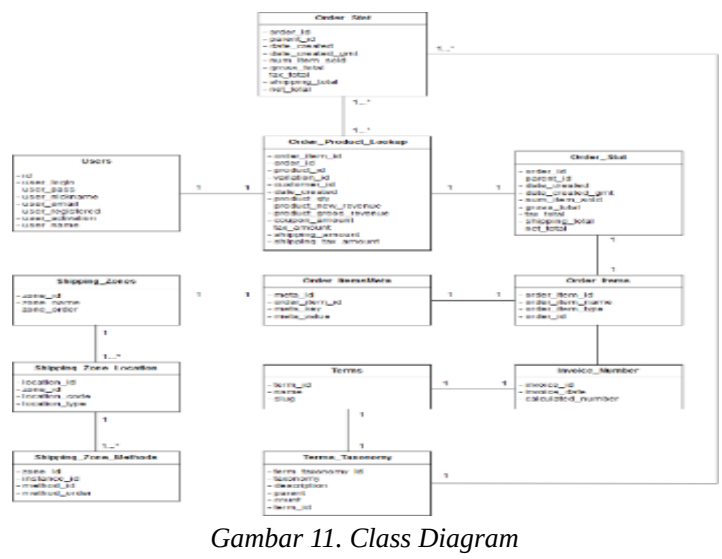

\subsection{System Sequence Diagram}

Diagram yang digunakan untuk mendefinisikan input dan output serta urutan interaksi antara pengguna dan sistem untuk sebuah Use Case[9]. Terdapat beberapa System Sequence Diagram yang digunakan pada penelitian ini, yaitu:

1) Proses Pendaftaran

Pada System Sequence Diagram Proses Pendaftaran. Terdapat suatu fungsi yang bertujuan untuk menyimpan data pendaftaran konsumen. Dapat dilihat pada gambar 12.

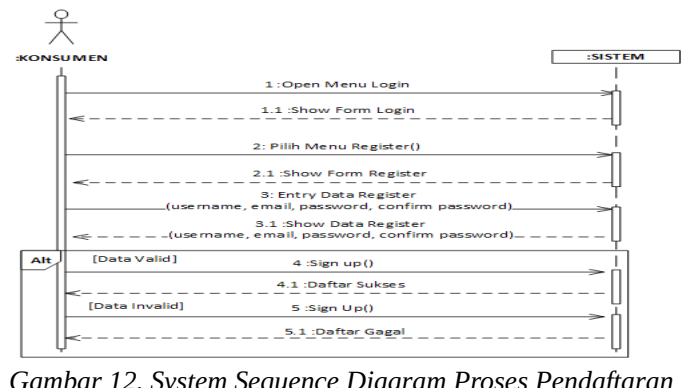


2) Proses Pemesanan

Pada System Sequence Diagram Proses Pemesanan. Terdapat suatu fungsi yang bertujuan untuk menyimpan data pemesanan konsumen. Dapat dilihat pada gambar 13 .

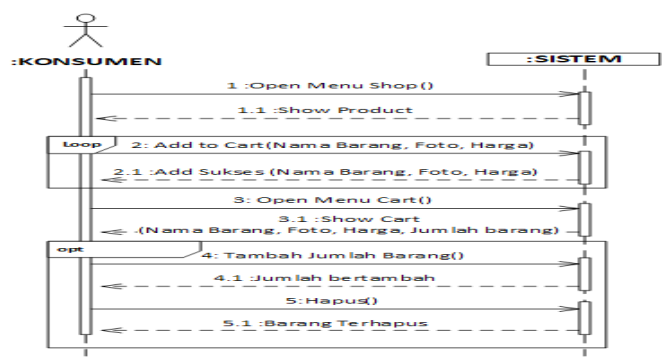

Gambar 13. System Sequence Diagram Proses Pemesanan

3) Proses Pembayaran

Pada System Sequence Diagram Proses Pembayaran. Terdapat suatu fungsi yang bertujuan untuk menyimpan data pembayaran. Dapat dilihat pada gambar 14 .

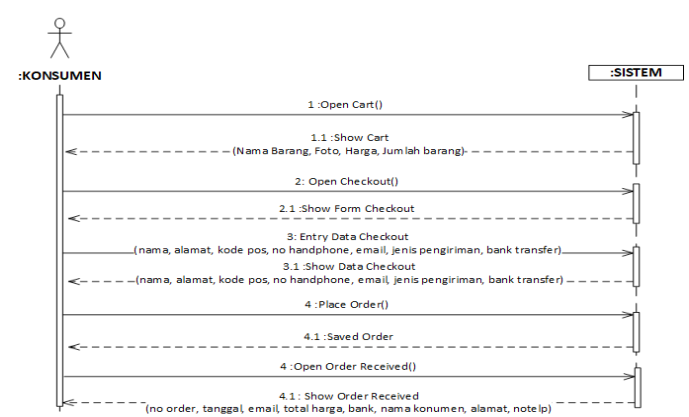

Gambar 14. System Sequence Diagram Proses Pembayaran

\section{4) Proses Pengiriman}

Pada System Sequence Diagram Proses Pengiriman. Terdapat suatu fungsi yang bertujuan untuk menyimpan data bukti pengiriman. Dapat dilihat pada gambar 15 .

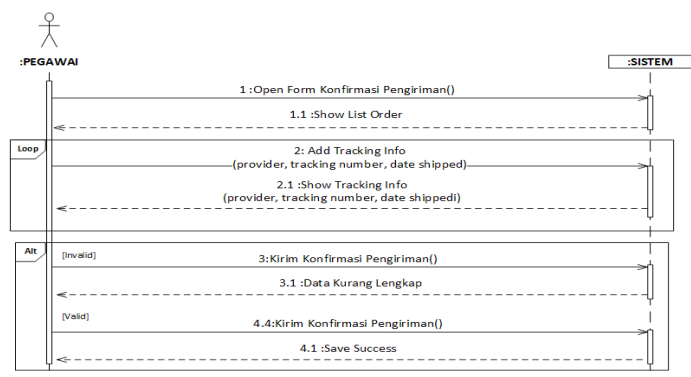

Gambar 15. System Sequence Diagram Proses Pengiriman

5) Proses Penerimaan Barang

Pada System Sequence Diagram Proses Penerimaan Barang. Terdapat suatu fungsi yang bertujuan untuk menyimpan data penerimaan barang. Dapat dilihat pada gambar 16.

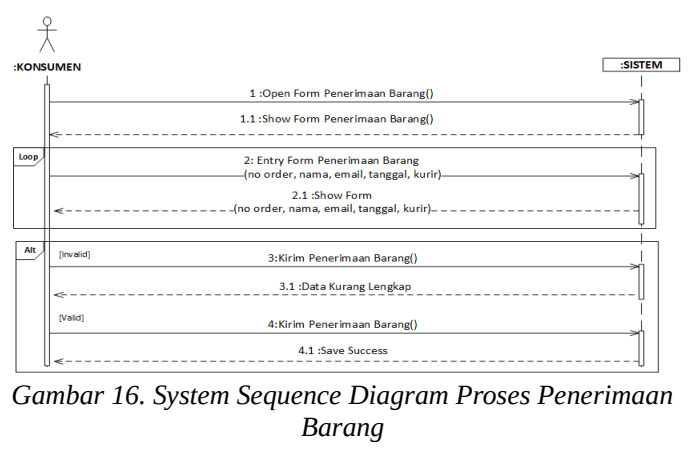

\subsection{Struktur Tampilan}

Terdapat Struktur Tampilan yang telah disusun bedasarkan dari program yang telah dibuat. Dapat dilihat pada gambar 17.

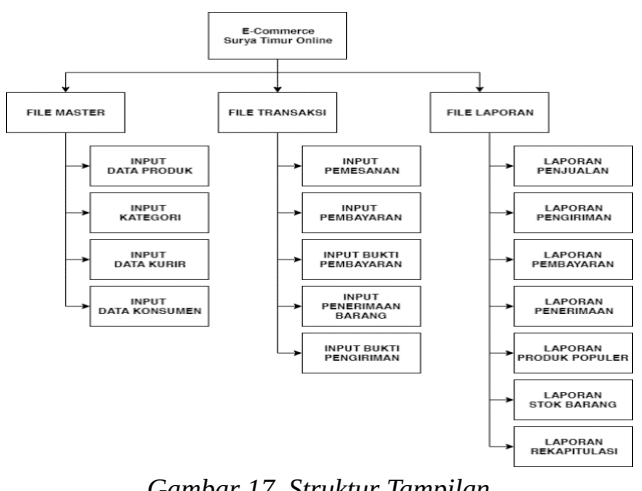

Gambar 17. Struktur Tampilan

\subsection{Business Model Canvas (BMC)}

Bahasa yang sama untuk menggambarkan, memvisualisasikan, menilai, dan mengubah model bisnis[10]. Terdapat elemen-elemen Business Model Canvas yang ada pada Surya Timur Collection. Dapat dilihat pada gambar 18.

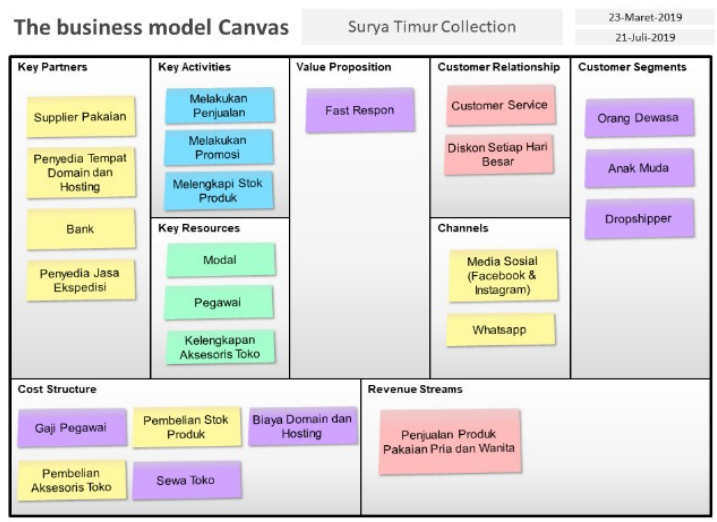

Gambar 18. Business Model Canvas

Bedasarkan gambar diatas, terdapat sembilan elemen yang ada pada Business Model Canvas yang 
telah di analisa sesuai dengan studi kasus Surya Timur Collection, yaitu:

Tabel 1. Tabel Bussiness Model Canvas

\begin{tabular}{|c|c|}
\hline Komponan BMC & Penjelasan \\
\hline Key Partners & $\begin{array}{ll}\text { 1. } & \text { Supplier pakaian } \\
\text { 2. } & \text { Penyedia tempat Domain \& } \\
& \text { Hosting } \\
\text { 3. } & \text { Bank } \\
\text { 4. } & \text { Penyedia jasa ekspedisi }\end{array}$ \\
\hline Key Activities & $\begin{array}{l}\text { 1. Melakukan penjualan } \\
\text { 2. Melakukan promosi } \\
\text { 3. Melengkapi stok produk }\end{array}$ \\
\hline Key Resources & $\begin{array}{l}\text { 1. Modal } \\
\text { 2. Pegawai } \\
\text { 3. Kelengkapan Aksesoris Toko }\end{array}$ \\
\hline Value Proposition & 1. Fast Respon \\
\hline Customer & 2. Customer Service \\
\hline Relationship & 3. Diskon setiap hari besar \\
\hline Channels & $\begin{array}{l}\text { 1. Media sosial (instagram \& } \\
\text { facebook) } \\
\text { 2. Whatsapp }\end{array}$ \\
\hline Customer Segments & $\begin{array}{l}\text { 1. } \text { Orang dewasa } \\
\text { 2. Anak muda } \\
\text { 3. } \\
\text { Dropshipper }\end{array}$ \\
\hline Cost Structure & $\begin{array}{l}\text { 1. Gaji pegawai } \\
\text { 2. Pembelian aksesoris toko } \\
\text { 3. Pembelian stok produk } \\
\text { 4. } \\
\text { 5ewa toko } \\
\text { Biaya Domain \& Hosting }\end{array}$ \\
\hline Revenue Streams & $\begin{array}{l}\text { Penjualan Produk Pakaian Pria dan } \\
\text { Wanita }\end{array}$ \\
\hline
\end{tabular}

\subsection{Rancangan Layar}

Terdapat 2 (dua) jenis Rancangan Layar bedasarkan program yang telah dibuat, yaitu:

1) Rancangan Layar Front-end

Terdapat beberapa Rancangan Layar Frontend, yaitu:

a) Home

Pada Rancangan Layar Home, terdapat rancangan dari halaman utama dari program yang telah dibuat. Dapat dilihat pada gambar 19.

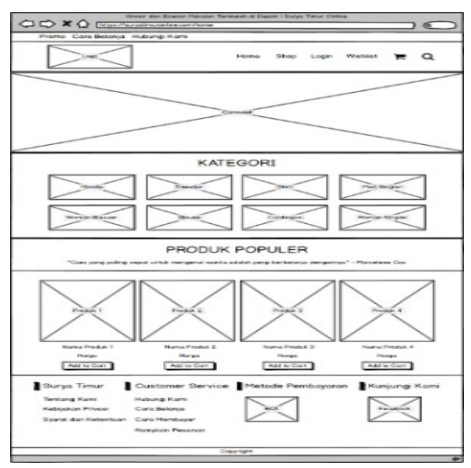

Gambar 19. Rancangan Layar Home

b) Login

Pada Rancangan Layar Login, terdapat rancangan dari halaman login dari program yang telah dibuat. Dapat dilihat pada gambar 20.

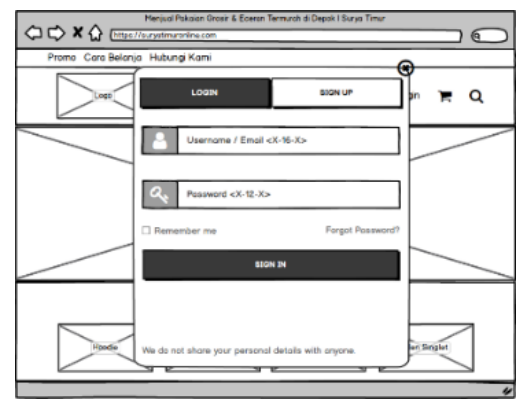

Gambar 20. Rancangan Layar Login

c) Register

Pada Rancangan Layar Register, terdapat rancangan dari halaman pendaftaran dari program yang telah dibuat. Dapat dilihat pada gambar 21.

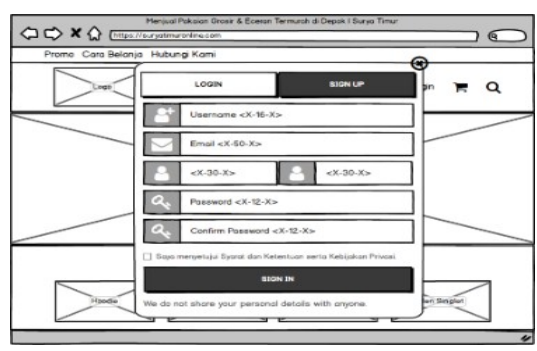

Gambar 21. Rancangan Layar Register

d) Konfirmasi Pembayaran

Pada Rancangan Layar Konfirmasi Pembayaran, terdapat rancangan dari halaman konfirmasi pembayaran dari program yang telah dibuat. Dapat dilihat pada gambar 22 .

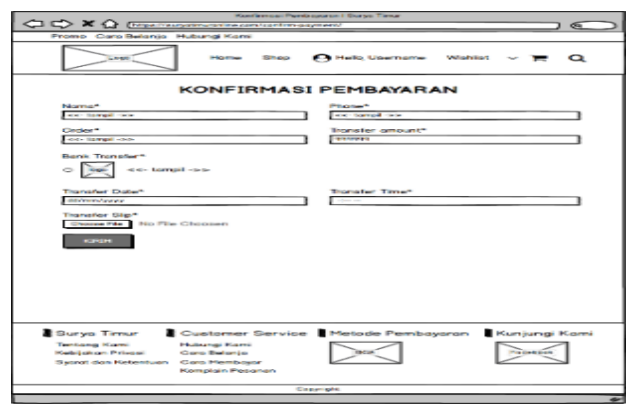

Gambar 22. Rancangan Layar Konfirmasi Pembayaran

2) Rancangan Layar Back-end

Terdapat beberapa Rancangan Layar Back-end, yaitu:

a) Tambah Produk

Pada Rancangan Layar Tambah Produk, terdapat rancangan dari halaman 
tambah produk dari program yang telah dibuat. Dapat dilihat pada gambar 23.

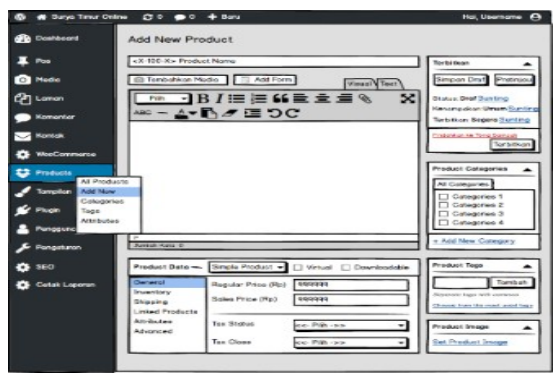

Gambar 23. Rancangan Layar Tambah Produk

b) Laporan Penjualan

Pada Rancangan Layar Laporan Penjualan, terdapat rancangan dari halaman laporan penjualan dari program yang telah dibuat. Dapat dilihat pada gambar 24.

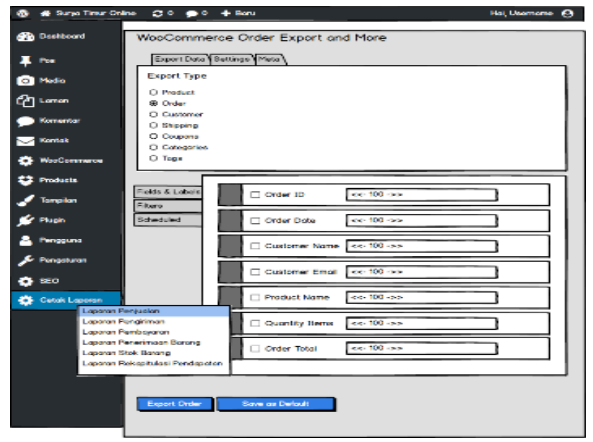

Gambar 24. Rancangan Layar Lapoan Penjualan

\subsection{Hasil Keluaran Program}

Terdapat hasil keluaran bedasarkan program yang telah dibuat, diantaranya adalah:

1) Notifikasi Detil Pemesanan

Terdapat hasil keluaran notifikasi detil pemesanan bedasarkan program yang dibuat. Dapat dilihat pada gambar 25 .

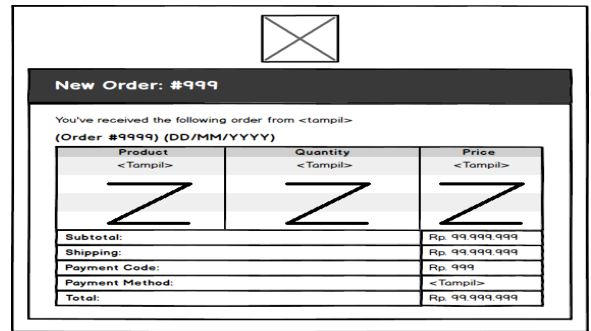

Gambar 25. Notifikasi Detil Pemesanan

\section{2) Laporan Penjualan}

Terdapat hasil keluaran laporan penjualan bedasarkan program yang dibuat. Dapat dilihat pada gambar 26.

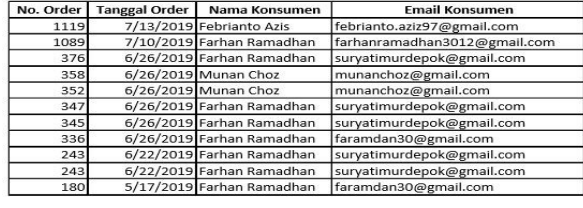

Gambar 26. Laporan Penjualan

\section{KESIMPULAN}

E-Commerce merupakan sarana bisnis yang menguntungkan untuk menaikan penjualan sehingga menjadikanya peluang bisnis yang digemari saat ini. Dalam implementasi sistem penjualan E-Commerce pada Surya Timur Collection terdapat beberapa kesimpulan:

a. Dengan adanya fitur keranjang belanja, maka proses pemesanan dapat menjadi lebih efektif untuk melakukan proses pemesanan.

b. Dengan adanya fitur laporan penjualan, maka pembuatan laporan dapat lebih mudah dan penyimpanannya lebih teratur tanpa harus takut kehilangan data.

c. Dengan adanya laporan stok barang pegawai dapat lebih mudah mengetahui jumlah stok yang tersedia pada saat konsumen melakukan pemesanan.

d. Dengan adanya sistem E-Commerce, maka Surya Timur Collection dapat mempermudah proses transaksi yang selama ini sifatnya konvensional menjadi lebih modern dengan tersedianya transaksi online dan data yang ada dapat dikelola dengan efisien.

e. Dengan adanya fitur promosi melalui sosial media yang ada Surya Timur Collection dapat memperluas pemasaran sehingga konsumen menjadi lebih mudah mendapatkan informasi tentang produk tanpa harus datang langsung ke toko Surya Timur Collection.

\section{DAFTAR PUSTAKA}

[1] A. Johnson, "Practical Communication Skill", Jakarta: Elex Media Komputindo, 2014.

[2] A. Dewangga, and B. Soepeno, "Penggunaan Aplikasi CMS Wordpress Untuk Merancang Website Sebagai Media Promosi pada Maroon Wedding Malang”, Jurnal Akuntansi, Ekonomi dan Manajemen Bisnis, pp. 63-69, 2014.

[3] R. P. Hastanti, B. E. Purnama, and I. U. Wardati, "Sistem Penjualan Berbasis Web (E-Commerce) Pada Tata Distro Kabupaten Pacitan”, Bianglala Informatika, 3(2), pp. 1-9, 2018.

[4] S. Rahman, “Kitab Sakti SEO”, Jakarta: Elex Media Komputindo, 2015.

[5] Andi, "Sukses Berbisnis Toko Online dengan Wordpress dan Woocommerce", Semarang: Wahana Komputer, 2015. 
[6] A. Prajatama, M. Rusli, and N. W. Deriani, "Aplikasi Multimedia Pembelajaran Interaktif Strategi Permainan Catur”, Jurnal Sistem dan Informatika, 9(2), pp. 24-35, 2015.

[7] A. Setyoningrum, P. I. Santosa, and N. A. Setiawan, "Analisis Kebutuhan Sistem Informasi Arsip Bangunan Berbasis User Centered Design (Ucd)". Prosiding Seminar Nasional Geotik 2017, pp. 157167, 2017.

[8] V. Yasin, "Rekayasa Perangkat Lunak Berorientasi Objek”, Jakarta: Mitra Wacana Media, 2012.

[9] E. Triandini, dan I.G. Suardika, "Step By Step Desain Proyek Menggunakan UML”, Yogyakarta: CV. Andi Offset, p. 71, 2012.

[10] A. Osterwalder, and Y. Pigneur, "Business Model Generation”, Jakarta: Elex Media Komputindo, 2012. 